UDC 378.147: 372

DOI: $10.31470 / 2415-3729-2018-8-225-237$

\title{
Essence and Structure of the Formation of Communicative Competence of Students
}

\author{
Tan Xiao \\ postgraduate student of the department of general pedagogy \\ and pedagogy of higher education \\ H. S. Skovoroda Kharkiv National Pedagogical University, \\ $\triangle$ 2, Valentynivska Str., Kharkiv, Ukraine, 61000 \\ E-mail: 47977911@qq.com \\ ORCID: 0000-0002-0740-8565
}

Date of receipt of the article: August 02, 2018

Article accepted for publication: November 25, 2018

\section{Суть i структура формування комунікативної компетентності студентів}

\section{Тань Сяо}

аспірант кафедри загальної педагогіки та педагогіки вищої школи, Харківський національний педагогічний університет імені Г. С. Сковороди,

$\triangle$ вул. Валентинівська, 2, м. Харків, Україна, 61000

Дата надходження статті: 01 серпня 2018 р. Стаття прийнята до друку: 25 листопада 2018 р.

\section{Abstract}

The article reveals the peculiarities of formation of students' communicative competence in the professional training process, which involves the formation of their communicatively meaningful personality traits, a pronounced humanistic tendency to communicate with pupils, the possession of a system of integrated professionalspeech skills and communicative qualities. The author defines the essence of the concept of «communicative competence of students» 
as a process and the result of professional training on the ability to subject-subjective interaction with colleagues of preschool age, which contains a complex of communication knowledge, skills and abilities. The benefit of the study is that a great attention is focused on creating the favorable conditions for the implementation of interpersonal communication in future professional activities.

The author of the article has made a conclusion that the analysis of scientific literature gives grounds to assert that the formation of students' communicative competence is understood by us as a process and the result of professional training on the ability to subject-subject interaction with colleagues and children of preschool age, which contains a complex of communication knowledge, skills and abilities. The author has also identified the components of the structure of the communicative competence formation, which include: motivational-cognitive (comprehension of the multifaceted personality, understanding of its desires; requirement and motives; positive attitude towards colleagues; feeling of community with the team); content (knowledge of norms and rules of communication and interaction, knowledge of ways to resolve conflicts); reflexive (effective use of communicative knowledge, skills and abilities that regulate the communication process, ability to collaborate in joint activities and communication with colleagues, use of constructive ways of resolving conflicts). The author of the article believes that the determining the essence and components of the formation of students' communicative competence will provide an opportunity to substantiate and develop the technology of forming the communicative competence of students in the process of professional training and its implementation in the educational process of H. S. Skovoroda Kharkiv National Pedagogical University.

Key words: communicative competence, formation, student, pedagogical institution of higher education.

\section{References}

1. Golub, B. G., Perelyigina, E. A. \& Fishman, I. S. (2012). Klyuchevyie kompetentsii studentov v kontekste trebovaniy novogo pokoleniya [Key competencies of students in the context of the requirements of the new generation]. Samara: OOO «Arbat» [in Russian]. 
2. Dobroskok, I. I. \& Portian, M. O. (2016). Suchasni oriientyry shchodo rozvytku intelektualnoi obdarovanosti osobystosti [Modern guidelines for the development of intellectual gifted personality]. In I. I. Dobroskok (Ed.) Profesiina osvita: teoretychni ta prykladni aspekty formuvannia kompetentnosti maibutnikh fakhivtsiv [Professional education: theoretical and applied aspects of competence development of future specialists] (Vol. 1, pp 7-21). Pereiaslav-Khmelnytskyi : FOP Dombrovska Ya. M. [in Ukraine]

3. Dyibina, O. V. (2008). Kompetentnostno-orientirovannyiy podhod $\mathrm{v}$ vospitanii doshkolnikov [Competence-oriented approach in the education of preschool children]. Tolyatti: TGU [in Russian].

4. Zimnyaya, I. A. (2004). Klyuchevyie kompetentsii kak rezultativno-tselevaya osnova kompetentnostnogo podhoda $\mathrm{V}$ obrazovanii [Key Competences as an Effective-Target Framework for a Competency Approach in Education]. Moskva: Nauchnoissledovatelskiy tsentr problem kachestva podgotovki spetsialistov [in Russian].

5. Kogut, A. A. (2018). Razvitie kommunikativnoy kompetentnosti detey starshego doshkolnogo vozrasta $\mathrm{v}$ muzyikalnoritmicheskoy deyatelnosti [Development of communicative competence of children of the senior preschool age in musical-rhythmic activity]. Candidate's thesis. Velikiy Novgorod: NovSU [in Russian].

6. Leontiev, A. A. (2004). Psihologiya obscheniya [Psychology of communication]. Moskva: Academy [in Russian].

7. Morozova, N. A. \& Reutskaya, N. A. (2014). K probleme realizatsii kompetentnostnogo podhoda $\mathrm{V}$ doshkolnom obrazovanii [To the problem of the implementation of the competence approach in preschool education]. Doshkolnoe obrazovanie i obuchenie - Early childhood education and training, 2, 105-109 [in Russian].

8. Palasevych, I. (2017). Komunikatyvna kompetentnist vykhovatelia ditei doshkilnoho viku [Communicative competence of educators of preschool age children]. Liudynoznavchi studii. Seriia «Pedahohika»-Human studies studios. Series «Pedagogics», 4/36. DOI: 10.24919/2313-2094.4/36.98634 [in Ukrainian].

9. Smirnova, E. O. \& Holmogorova, V. M. Mezhlichnostnyie otnosheniya doshkolnikov: diagnostika, problemyi, korrektsiya [Interpersonal relations of preschool children: diagnostics, 
problems, correction]. Moskva: Gumanitarnyiy izdatelskiy tsentr VLADOS [in Russian].

10. Hutorskoy, A. V. (2005). Tehnologiya proektirovaniya klyuchevyih i predmetnyih kompetentsiy [Technology of designing key and subject competencies]. Eydos - Eidos, 3, $27-39$ [in Russian].

\section{Introduction}

At the present stage of a society development, the priority task of higher education is to prepare highly qualified specialists who are able not only to operate with their own knowledge, but also to change and adapt to the new needs of the labor-market, to act actively and enrich professional experience. The importance of educating young people by competent specialists is undeniable, because it is the teacher's personality, its erudition and culture from which the successful solution of the tasks of training and educating the future generation depends on.

The problem of forming the specialists' communicative competence is the subject of scientific research of modern language pedagogues. Such scientists as A. Bohush, A. Nikitina, I. Palasevych, O. Semenoh, T. Symonenko, Ye. Yehorova and others consider the content of communicative competence on the basis of competence approach to language learning, differentiation of concepts competence and competency speech characteristics (orientation in the situation of speech, possession of the system of knowledge and rules of behavior during communication, the use of expressive means of language).

The relevance of the research and the absence of its holistic research determined the choice of the topic of the proposed article, the purpose of which is to determine the essence and components of the formation of students' communicative competence in the process of professional training.

\section{Materials and Methods}

A number of scientific search methods were used for the research, in particular - analysis, synthesis, generalization and systematization of scientific literature.

\section{Results and Discussion}

In the course of the research, the essence and structure of the formation of communicative competence of students in the process of professional training was determined. 
The following research methods were used in solving the set tasks and achievement of the set goal: analysis of pedagogical and psychological scientific works, systematization of attitudes and achievements of scientists (to determine the state of development of the problem, to determine the essence of the research basic concepts, to develop the methodological foundations of forming the future educators' communicative competence).

The concept of competence is the key to a competent approach, which with the spread of ideas of continuing education has become widely used in pre-school education.

Thus, A. Khutorskyi understands a competence as the alienated, predetermined social requirement (norm) for the educational preparation of a person, which is obligatory for its effective activity in a certain area (Hutorskoy, 2005).

Competence is mastering the corresponding complex of individual qualities of personality (knowledge, skills, abilities, capabilities), determined by the experience of its activities in any social or educational-professional field (Hutorskoy, 2005).

I. Zymnia emphasizes that competence is hidden, probable, potential person's capabilities (knowledge, skills, representation, desire, program of actions, system of values and relations), which are realized in its current and activity manifestations. By the competence, the scientist understands intellectually and personally determined social and professional activity of a person (Zimnyaya, 2004).

Relying on the statement of psychologists: a person is the subject of communication, knowledge, labor (B. Ananiev); a person manifests itself in relation to society, to other people, to himself as a person, to work (V. Miasyshchev); the competence of a person has a vector of acmeological development (N. Kuzmina), I. Zymnia identified three groups of key competencies:

- competence relating to the attitude to oneself as an individual, as a subject of life activity;

- competencies relating to human relations with other people;

- competencies related to human activities that are manifested in all its types and forms (Zimnyaya, 2004).

I. Fishman, B. Holub, E. Perelyhina define a competence as a system of values, knowledge, abilities and skills, which is adequately 
realized in the activity of the individual in solving the necessary tasks. A competence is understood as a qualitative characteristic, the realization by a person in the educational process of acquired knowledge, general methods of action, knowledge and practical skills, appear in the ability and readiness of an individual to actively and productively use acquired education to solve important social and personal educational and practical tasks to achieve high results according to life goals. Scientists define the essence of the concept of «competence» as an educational result (Golub, Perelyigina \& Fishman, 2012).

N. Morozova, N. Reutska consider competence as the ability to make decisions independently and act in accordance with generally accepted cultural norms, knowledge and gained experience (Morozova \& Reutskaya, 2014).).

A competence (according to I. Palasevych) is a set of certain knowledge, abilities, skills, personal qualities in the corresponding field of activity, ability to solve problems in professional activity (Palasevych, 2017).

With regard to the definition of the essence of the concept of «communicative competence» and its components, one should take into account the specifics of training specialists in the relevant fields and specialties.

As for the definition of the essence of the concept of «communicative competence» and its components, then the specifics of training specialists in relevant industries and specialties should be taken into account.

I. Palasevych notes that the communicative competence of educator of preschool children implies the formation of communicatively significant personality traits, a pronounced humanistic tendency to communicate with pupils, the readiness to set up a subject-subject interaction, the possession of a system of integrated professional-language skills, and communicative qualities.

The scientist defines the following components: a system of communicative knowledge (in particular in the field of psychology of communication, general-didactic, professional, methodological); communicative skills and abilities (ability to speak, listen, establish contact with an interlocutor, understand its inner state, manage 
interaction, apply constructive behavior in conflict situations, expressive skills and so on); communicative abilities (features and professionally significant personal qualities), as well as moral convictions (worldview, ethical view, value orientations and motives of activity) (Palasevych, 2017).

Note that there is no single approach to the classification of communicative competence, but many researchers point out that this:

- a set of abilities (Ye. Alifanova, O. Dybina);

- a set of personality traits (L. Trubaichuk);

- ability to communicate (T. Avdulova, H. Khuzieieva, L. Znikina etc.).

Since the relevant skills that the subject must master, due to the combination of acquired knowledge, is an integral part of communicative competence, then O. Dybina identifies the following skills in the structure of communicative competence as: of others;

an ability to correctly recognize and interpret emotions

- an ability to receive the necessary information in the course of communication;

- an ability to listen and hear a partner, respect the attitude and interests of others;

- an ability to conduct constructive dialogue;

- an ability to maintain emotional calm when substantiating its own point of view;

- an ability to relate their desires and interests with the aspirations and interests of other people;

- an ability to do a common cause;

- $\quad$ an ability to help others and receive help;

- an ability to solve conflict situations (Dyibina, 2008).

O. Dybina identifies the following structural components of the communicative competence of students: cognitive, emotional, and behavioral (Dyibina, 2008).

The conducted analysis of scientific literature provides grounds to distinguish the following components of the formation of students' communicative competence in the process of professional training:

1) motivational-cognitive:

- awareness of the versatility of the individual, understanding of its desires, 
- needs and motives;

- positive attitude towards colleagues;

- feeling of community with the team;

2) content: interaction;

- knowledge of norms and rules of communication and

- knowledge of ways to resolve conflicts;

3) reflexive:

- effective use of communicative knowledge, skills and abilities that govern the communication process;

- ability to work together and collaborate with colleagues;

- use of constructive ways to resolve conflicts.

Some scientists (T. Avdulova, H. Khuzieieva, L. Svirska, L. Znikina and others) are convinced that the manifestation of the development of the communicative competence of an individual is a communicative activity itself.

We cannot disagree with this point of view, because for the constructive analysis of the content and structure of the communicative competence of future educators, we consider the essence of the concept of association, communication and communicative activities, as well as the peculiarities of communicative activities of students in the process of professional training.

The problem of communicating and interpersonal relations was a matter for humanity from an ancient time. Plato emphasized the inability of man to meet all his needs independently and as a result attract other people to this action. Relations that arise between people as a result of communication are defined by them as «reasonable relations of mutual use».

Aristotle should be called the creator of the first scheme of human communication, because, according to the philosopher, for any act of communication, at least three components are needed:

- person speaking;

- language in which the person communicates;

- person who listens to this speech.

Throughout the ages, the problem of communication was considered from the standpoint of various philosophical directions: existentialism, hermeneutics, information mutual enrichment and like that. 
Therefore, the analysis of scientific literature (O. Leontiev, S. Rubinshtein, L. Vyhotskyi and others) provides grounds for defining communicative activity as interpersonal interaction, in which process is carried out not only the exchange of ideas, but information enrichment of the participants of communication.

However, some scholars differentiate between the concepts of «intercommunication» and «communication», since communication is an element of intercommunication, and intercommunication is an integral part of communication, depending on the meaning that embeds in each of researchers.

In accordance with the concept of O. Leontiev, the following structural elements of communicative activity should be distinguished:

- motives for communication, that is what the person is guided by contacting others; self-knowledge;

a need for communication - personal aspiration for

- a task of communication - a sequence of actions that are carried out in the communication process necessary to achieve a specific goal;

- communicative possibilities - are a collection of spiritual and material values through which communication is carried out (Leontiev, 2004).

Therefore, in the context of this problem, we define the essence of the concept of "communicative activity» as an interpersonal interaction in which perception, evaluation and understanding of others are carried out, the information enrichment of the subjects of interaction takes place, and the result of this process will be the formation of stable interconnections that arise in the process of communication.

It should be noted that in the process of forming the communicative competence of students, it should be emphasized that the construction of an algorithm for communicating with children of preschool age is a priority task, since the communication of children of preschool age does not depend on the subjects and practical actions with them.

In the researches of scientists (O. Cherenkova, H. Kobelieva, O. Kulykova, L. Kutsakova, M. Lavrentieva, I. Marvina, 
S. Proniaieva, Ye. Smyrnova, L. Shchepitsina and others) it is proved, that in the period of 5-7 years the structure of preschool group sharply grows: some children occupy the position of leaders, after which the majority of group members goes, others are disadvantaged. Special hidden relationships are forming between children, also as a special status position of each child in the group.

Some children are popular, respectful, they want to interact with most of the children in the group, while others, on the other hand, remain «on the side» from the team, they do not want to play with them. In a senior preschool age, a child needs to compare itself with others, which is the result of not establishing community, but contrasting itself and other children.

V. Kholmohorova, Ye. Smyrnova note in their research that children reach highest development level of cooperation in older preschool age and unlike in middle preschool age, the opportunities for communication increase significantly, since children share their ideas and plans with each other, give assessments to others (Smirnova \& Holmogorova, 2005).

Therefore, it is important that the formation of students' communicative competence, as a result of its formation, becomes of great importance, because in future professional activity it will depend on the following:

- the ability of preschool children to interact with each other, consisting of the skills to see and coordinate their actions with other children, to provide mutual assistance and mutual control, to evaluate the result of joint activity;

- the ability to partner dialogue, including skills to listen to a partner, negotiate with him or her, empathy;

- the ability to perceive oneself as a member of a group, which includes a positive attitude towards oneself and others (Kogut, 2018).

\section{Conclusion}

Consequently, the analysis of scientific literature gives grounds to assert that the formation of students' communicative competence is understood by us as a process and the result of professional training on the ability to subject-subject interaction with colleagues and children of preschool age, which contains a complex of 
communication knowledge, skills and abilities. The components of the structure of communicative competence formation are identified, including such components as: motivational-cognitive, content and reflective. Motivational and cognitive component in the formation of students' communicative competence contributes to awareness of the versatility of an individual, understanding its desires, needs and motives, positive attitude towards colleagues, feeling of community with the team. As for the content component of the formation of students' communicative competence - it contains of knowledge on norms and rules of communication and interaction, knowledge of ways to resolve conflicts. The composition of the reflective component of the formation of students' communicative competence should include the effective use of communicative knowledge, skills and abilities that govern the communication process, ability to work together and collaborate with colleagues and use of constructive ways to resolve conflicts.

Determining the essence and components of the formation of students' communicative competence will provide an opportunity to substantiate and develop the technology of forming the communicative competence of students in the process of professional training and its implementation in the educational process of H. S. Skovoroda Kharkiv National Pedagogical University.

\section{Тань Сяо}

\section{Суть і структура формування комунікативної компетентності студентів}

\section{Анотація}

У статті розкрито особливості формування комунікативної компетентності студентів у процесі професійної підготовки, що передбачає сформованість у них комунікативно значущих особистісних рис, яскраво виражену гуманістичну схильність до спілкування 3 вихованцями, володіння системою інтегрованих професійно-мовленнєвих умінь та комунікативних якостей. Автором визначено суть поняття «комунікативна компетентність 
студентів» як процес $\mathrm{i}$ результат професійної підготовки щодо здатності до суб'єкт-суб'єктної взаємодії 3 колегами та учнями, яка містить комплекс комунікаційних знань, умінь та навичок. Виявлено складові структури формування комунікативної компетентності, які включають: мотиваційнопізнавальну (розуміння багатогранної особистості, розуміння iii бажання; вимоги та мотиви; позитивне ставлення до колег; почуття спільності з колективом) ; зміст (знання норм і правил спілкування і взаємодії, знання шляхів вирішення конфліктів); рефлексивний (ефективне використання комунікативних знань, умінь i навичок, що регулюють процес спілкування, вміння співпрацювати в спільних заходах і спілкуванні 3 колегами, використання конструктивних шляхів вирішення конфліктів). Акцентовано увагу на створенні сприятливих умов для реалізації міжособистісної комунікації у майбутній професійній діяльності. Визначено компоненти структури формування комунікативної компетентності, до яких віднесено: мотиваційно-пізнавальний (усвідомлення багатогранності особистості, розуміння ii бажань; потреби та мотиви; позитивне ставлення до колег та учнів; відчуття спільності 3 колективом); змістовий (знання норм i правил спілкування i взаємодіï; знання про способи вирішення конфліктів); рефлексійний (ефективне використання комунікативних знань, умінь та навичок, що регулюють процес спілкування; здатність до співпраці у спільній діяльності і в спілкуванні 3 колегами та учнями; використання конструктивних способів вирішення конфліктів). Автор статті вважає, що визначення сутності і компонентів формування комунікативної компетентності студентів дасть можливість обгрунтувати i розкрити технологію формування комунікативної компетентності студентів у процесі професійної підготовки та іiі впровадження в освітню процес Харківського національного педагогічного університету ім. Г. С. Сковороди.

Ключові слова: комунікативна компетентність, формування, студент, педагогічний заклад вищої освіти. 


\section{Тань Сяо}

\section{Сущность и структура формирования коммуникативной компетентности студентов}

\section{Аннотация}

В статье раскрыты особенности формирования коммуникативной компетентности студентов в процессе профессиональной подготовки, предполагает сформированность у них коммуникативно значимых личностных черт, ярко выраженную гуманистическую склонность к общению, владение системой интегрированных профессионально-речевых умений и коммуникативных качеств. Автором определена суть понятия «коммуникативная компетентность студентов» как процесс и результат профессиональной подготовки способностью к субъектсубъектной взаимодействия с коллегами, которая содержит комплекс коммуникационных знаний, умений и навыков. Акцентировано внимание на создании благоприятных условий для реализации межличностной коммуникации в будущей профессиональной деятельности. Определены компоненты структуры формирования коммуникативной компетентности, к которым отнесены: мотивационно-познавательный (осознание многогранности личности, понимание его желаний; потребности и мотивы; позитивное отношение к коллегам и детем, ощущение общности с коллективом) содержательный (знание норм и правил общения и взаимодействия, знание о способах разрешения конфликтов) рефлексионные (эффективное использование коммуникативных знаний, умений и навыков, регулирующих процесс общения, способность к сотрудничеству в совместной деятельности и в общении коллегами и детьми, использование конструктивных способов разрешения конфликтов).

Ключевые слова: коммуникативная компетентность, формирование, студент, педагогический учреждение высшего образования. 